\title{
Research on preliminary concept of ship intended for mining poly-metallic concretions from sea bed
}

\author{
Monika Bortnowska, \\ Szczecin University of Technology
}

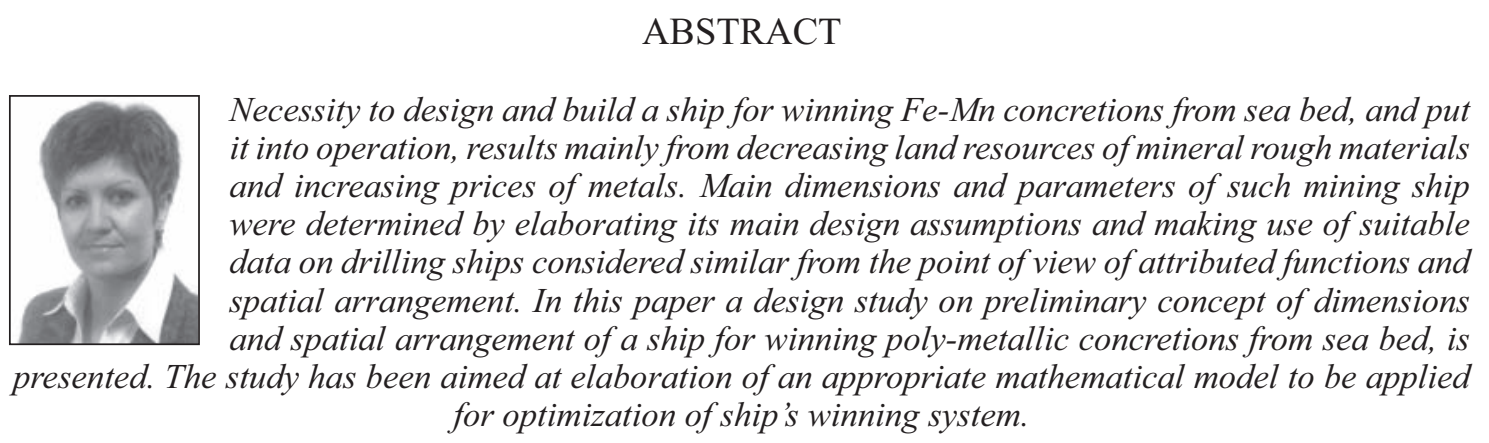

Keywords: deposits of Fe-Mn concretions, design assumptions, concept of mining ship, main parameters and dimensions of mining ship.

\section{INTRODUCTION}

Sea-bed concretions are poly-metallic minerals which can be found in deep water regions of seas and oceans. They usually are spread over sea - bed in the form of a single layer of irregular oval solids of 3-10 cm diameter, usually. Density of the concretions depending on their chemical composition amounts to about $2-3 \mathrm{~g} / \mathrm{cm}^{3}$ on average. Water content of the concretions reaches $40 \%$ of their dry weight and their average chemical composition usually assumed to economic analyses is as follows : manganese $-25 \%$, iron $-15 \%$, nickel $-1.25 \%$, copper $-1.25 \%$, cobalt $-0.25 \%$. Also, small amounts of lead, molybdenum, vanadium, titanium and other metals can be present [4].

Fe-Mn concretions have not been so far mined on industrial scale firstly because of lack of legal regulations dealing with sea and ocean bed areas outside state jurisdiction zones, secondly because of high investment costs associated with mining process and thirdly because of lack of a feasible industrial technology for winning the concretions from ocean bed.

Presently, Poland - being a member of Interoceanmetal Common Organization, one of international consortia - has a chance to get access to sea-bed deposits of Fe-Mn concretions occurring at a water depth of over $4000 \mathrm{~m}$ in Clarion-Clipperton field of the Pacific Ocean. The field is of a special value characterized by a high specific concentration of concretions amounting to over $10 \mathrm{~kg} / \mathrm{m}^{2}$ and simultaneously by the highest concentration of metals in the concretions [7].

The mining of the valuable rough materials is one of the most promising ways of winning metal ores from sea bed; their exploitation can result in important changes on the world market of metals in the future. Taking into account possible present applications of automated mining complexes (on development of which intensive work is carried out in the most developed countries of the world) and possible applications of modern techniques of processing the concretions, one can deem continuation of work on development of resources of concretions to be an important task in prospect of the year 2020 [7].

\section{TECHNIQUE AND SYSTEM OF MINING FE-MN CONCRETIONS}

For realization of mining process of the concretions from sea bed it will be necessary to design and build a large technical system of high reliability and possibly low cost of operation. The complete designed system for industrial mining and transport of Fe-Mn concretions will contain:

1. mining and transport system:

- mining ship

- winning installation

- bottom gathering vehicle

- floating pipe line for reloading the concretions from mining ship to transport ship,

2. transport and supply ships

3. ships for technical support and rescue actions at sea, and, the operational process will be considered as that of a complete system consisted of mining, storing, transporting and processing devices. 
In the case if industrial exploitation of concretions resources of and a large depth of their winning is considered the mining system is to be adjusted to realization of multi-year operation process difficult from the point of view of engineering and organization of work.

The winning process of the $\mathrm{Fe}-\mathrm{Mn}$ concretions from deep water - being the main task of the mining system- will be realized by the conventional single-hull ship (1) fitted with the hydraulic winning pipe line (2) and the bottom self-propelled gathering vehicle (3), Fig. 1. This is one of the most often proposed concepts of rough material mining, which can be aplied for elaboration and possible modification of a concept of mining system and ship. The mining ship plays main role in the whole mining system as it makes correct functioning - by keeping at position and supplying electric power both to the bottom gathering vehicle and winning pipe line, possible.

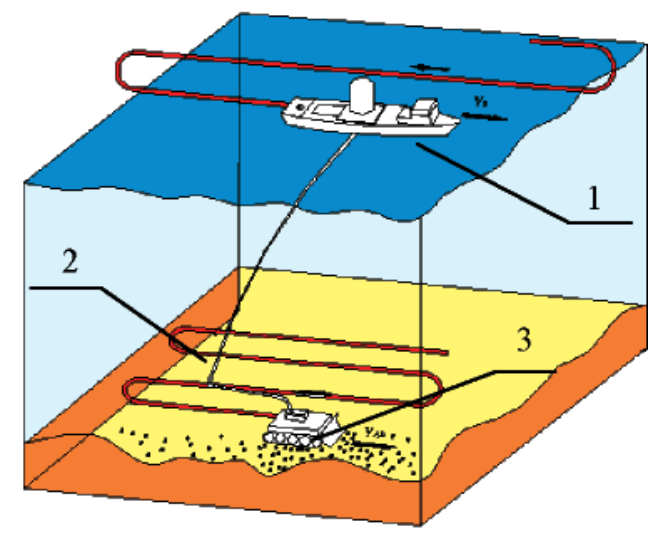

Fig. 1. Schematic diagram of mining system for Fe-Mn concretions

The main function of the mining ship is to win the concretions from sea bed by making use of a suitable winning system and then after collecting appropriate amount of the concretions in its holds to reload the win to transport ships by means of a transport pipe line floating on water surface.

Bottom gathering vehicle (self-propelled) will make it possible to gather concretions from sea bed. Moving over sea bed along a given route it will be able to change its speed and direction of motion depending on sea bed shape and encountered obstacles (large boulders, cracks etc). Though the vehicle will be connected with the buffer of the winning vertical pipe with the use of elastic zero-buoyancy transport piping, motions of the mining ship with lowered winning installation must be correlated with those of the gathering vehicle.

For transporting the concretions from sea bed will serve the vertical winning pipe line hung to ship hull and connected with bottom gathering vehicle. The so long pipe will be exposed to permanent changes of its position and deformations in sea depth due to motions of the mining ship and gathering vehicle as well as sea current action. During winning the concretions the winning pipe line cannot disturb motion of bottom gathering vehicle.

Out of all winning methods the greatest chance of application is attributed to hydraulic or pneumatic-hydraulic ones (hoisting the concretions by means of a working medium contained in piping installation) because of high operational capacity and reliability required for industrial exploitation of concretions resources. And, it may be a single-pipe or twin-pipe installation depending on location of water pumps (if singlepipe one then deep-well pumps are used, if twin-pipe one then water pumps are installed inside ship hull). The above presented concepts influence design of mining ship and in consequence the whole designed model (at least from the point of view of the system's resistance to motion).

\section{PRELIMINARY DESIGN PROCESS OF MINING SHIP}

Problem of determination of main design parameters of mining ship confronts its designer to much more difficult task than that in the case of designing typical transport ships such as: containerships, bulk carriers, tankers etc because of lack of population of existing mining ships, as well as of information on size and amount of special equipment and devices which greatly influence ship's dimensions.

Formulae and algorithms used in the traditional design methods have been implemented to shipbuilding practice as a result of collecting experience, drawing conclusions or observations on technical and operational features of existing ships. In consequence there are in use various methods of theoretical, statistical or empirical nature, for instance calculation algorithms containing formulae, equations, coefficients and diagrams which express relations between ship parameters and its technical features, which can not be used in the considered case.

Because of lack of existing ships or even only designed ones intended for industrial exploitation of $\mathrm{Fe}-\mathrm{Mn}$ concretions and resulting from it large number of unknowns concerning a.o. design dimensions and masses, ship body geometry, it was necessary to make use (for designing purposes) of population of drilling ships deemed similar to the above mentioned from the point of view of their geometry and dimensions, spatial arrangement, amount of special equipment etc.

\section{Requirements for elaboration of a general concept of mining ship}

The mining ship constitutes a crucial element of the whole mining system whose mission is to win a given amount of wet concretions per year from sea-bed.

Spatial arrangement of mining ship is strictly depending on its function. Its casing containing a stabilized hoist tower which supports winning pipe line, is located amidships. Systems of a special functional unit and that maintaining the winning operations are placed in the neighbourhood of the hoist tower. Near the casing a compartment for preliminary cleansing the concretions and system of internal transport devices is located. The ship's holds should be so designed as to make it possible to uniformly load and reload concretions by means of an appropriate system. Capacity of holds results from winning effectiveness and storing time interval of concretions in the holds. And, the storing time interval is directly depending on : number and size of transport ships (their load capacity), their service speed as well as a distance from port of destination.

Design of mining ship should - as far as its size and spatial arrangement is concerned - ensure the following quantities:

$\partial$ an appropriate loading space for temporary storing the concretions

$\rightarrow$ an appropriate volume of space amidships to install winning pipe line system

$\vec{\theta}$ in the vicinity of the winning system - an appropriate compartment to locate devices for initial cleansing and transporting the concretions to ship holds

$\rightarrow$ an appropriate area amidships to spread and store pipes of winning system

a sufficiently large space to accommodate ship power plant (which results from large power demand for numerous power consumers, mainly drives of propellers applied in motion control system, and devices for winning, processing and transporting the concretions etc) 
2 an appropriate area or space for location a large number of various ship systems and auxiliary devices (preferably in compartments sheltered against atmospheric exposure, in which the devices would be grouped depending on a kind of their work)

an appropriate capacity of tanks and stores to accommodate various supplies resulting from an assumed autonomy of the ship

$\rightarrow$ an appropriate space for living and social accommodations sufficiently distant from sources of noise and vibration.

Hence for mining ship the main design problem is to determine size and on board location of the devices which have to ensure realization of the winning process of concretions at fulfilled design assumptions and in assumed weather conditions. Knowledge of quantities which characterize the devices would make it possible to determine deadweight of a designed mining ship and consequently its dimensions.

\section{Main design assumptions for mining system}

To elaborate the mining ship design concept the following main design parameters were formulated :

$>$ the yearly rate of winning the wet concretions, $\mathrm{Q}_{\mathrm{MK}}$

$>$ the time interval of storing the concretions in mining ship holds $\mathrm{T}_{\mathrm{SK}}$ (the ship's load capacity $\mathrm{P}_{£}$ will result from both the above given parameters, $\mathrm{T}_{\mathrm{SK}}$ and $\mathrm{Q}_{\mathrm{MK}}$ )

$>$ the average concentration per unit area of the concretions in sea bed deposit

$>$ the water depth from which the concretions have to be won

$>$ the maximum design sea conditions in which the winning process has to be continued.

Both the time interval of storing the concretions in ship holds and sea conditions in mining field region decisively influence ship's size, and the winning depth and the unit area concentration of the concretions in their deposit influence mainly rate of gathering the concretions from sea bed, which also influences the ship's speed of motion over the mining field.

On the basis of the performed economic analyses and the published results and data dealing with the deposit of polymetallic concretions [5] the following design assumptions were selected for further considerations:

$\star$ Values of the yearly rate of winning the concretions:

\begin{tabular}{|c|c|c|c|}
\hline $\begin{array}{c}\text { Rate of winning } \\
\text { the dry } \\
\text { concretions } \\
\mathbf{Q}_{\mathrm{SK}} \text { [t/year] }\end{array}$ & 1.000 .000 & 1.250 .000 & 1.500 .000 \\
\hline $\begin{array}{c}\text { Rate of winning } \\
\text { the wet } \\
\text { concretions } \\
\mathbf{Q}_{\mathrm{MK}}[\mathbf{t} / \mathbf{y e a r}]\end{array}$ & 1.400 .000 & 1.750 .000 & 2.100 .000 \\
\hline $\begin{array}{c}\text { Theoretical rate } \\
\text { of winning } \\
\text { the concretions } \\
\mathbf{Q}_{\text {teor }}[\mathbf{t} / \mathbf{h}]\end{array}$ & 200 & 250 & 300 \\
\hline
\end{tabular}

$\star$ The time interval of storing the concretions in ship's holds $\mathrm{T}_{\mathrm{SK}}$ from which ship's load capacity results (volume of the holds)

$\star$ The average unit area concentration of the concretions $\rho_{\mathrm{k}}=10 \mathrm{~kg} / \mathrm{m}^{2}$

$\star$ The water depth of winning $\mathrm{h}_{\mathrm{w}}=4600 \mathrm{~m}$.
The effective operation time interval $\mathrm{T}_{\mathrm{e}}$ was determined by means of the following relation:

$$
\mathrm{T}_{\mathrm{e}}=365-\mathrm{t}_{\mathrm{r}}-\mathrm{t}_{\mathrm{p}}[\text { days }]
$$

where:

$\mathrm{t}_{\mathrm{r}}-$ yearly down-time interval resulting from technological causes

$t_{p}-$ yearly down-time interval resulting from bad weather conditions.

For $t_{r}$ and $t_{p} 20 \%$ of yearly time resources was assumed according to [5].

To determine ship's load carrying capacity it is assumed that the concretions (at their average wet density $\rho_{\mathrm{mk}}=2 \mathrm{t} / \mathrm{m}^{3}$ ) will be stored in ship's holds during the assumed time interval (assuming that ship's holds are filled up in $96 \%$ and some capacity margin is maintained for possible delays in reloading the concretions to transport ship without any break of the winning process).

\section{ELABORATION OF SIMPLIFIED VARIANTS OF MINING SHIP}

\section{The first estimation of main parameters of mining ship}

For the first estimation of main dimensions of mining ship were used the statistical data on drilling ships - assumed similar regarding their functions and spatial arrangement. Moreover the drilling ships are usually equipped with a dynamic positioning system $(D S P)$ which makes it possible to maintain a set ship's position over a bore-hole. In the case of mining ship the above mentioned system will be one of those necessary for carrying out mining operations as it allows for - apart from maintaining a set ship's position and course - also moving the ship with controlled speed along a set trajectory within a given corridor. The DSP system is of importance as its power demand is crucial for size of ship, and its areas first of all. Hence to estimate the main dimensions of mining ship it was necessary to take into account $D S P$ system's power output and sea conditions for which the ships had to be designed. The ship main dimensions and $D S P$ system's power output are mutually related. Increasing the ship's main dimensions or displacement is associated with simultaneous increasing the power demand, that makes initial and operational costs of ship increasing and - in consequence - adversely influences profitability of the whole mining process. Therefore it is very important to so elaborate design of the mining ship as to make its size and power demand optimum.

From economic point of view it is equally important to set the maximum permissible sea conditions (in which the designed ship has to operate) on a reasonable level so as to obtain operational costs acceptable. In this connection a compromise between down-time interval, ship's effectiveness and financial reasons is searched for. Hence the range of design weather conditions should be taken into account during realization of the ship's design.

On the basis of the collected data on drilling ships (Tab. 1 and 2) a regression analysis was performed (by using Statistica software) between the main dimensions and characteristics of the drilling ships, that crucially influence $D S P$ system's power output. Their results in the form of regression relationships were used to elaborate a preliminary concept of mining ship dimensions.

In Fig. $2 \div 4$ of this paper are graphically illustrated only a few statistical analyses selected from [2, 3], which made it possible to estimate - in the first approximation - the main dimensions of the designed mining ship. 
Tab. 1. Main dimensions and parameters of drilling ships

\begin{tabular}{|c|c|c|c|c|c|c|c|c|c|c|c|c|}
\hline No. & Drilling ships & $\begin{array}{c}\mathbf{h}_{\mathbf{w r}} \\
{[\mathbf{m}]}\end{array}$ & $\begin{array}{c}\mathbf{L}_{\mathbf{b p}} \\
{[\mathbf{m}]}\end{array}$ & $\begin{array}{c}\mathbf{B} \\
{[\mathbf{m}]}\end{array}$ & $\begin{array}{c}\mathbf{H} \\
{[\mathbf{m}]}\end{array}$ & $\begin{array}{c}\mathbf{T} \\
{[\mathbf{m}]}\end{array}$ & $\mathbf{P}_{\mathbf{N}}[\mathbf{t}]$ & $\begin{array}{c}\Delta \\
{[\mathbf{t}]}\end{array}$ & $\begin{array}{c}\mathbf{S}_{\mathbf{y}_{\mathbf{y}}} \\
{\left[\mathbf{m}^{2}\right]}\end{array}$ & $\begin{array}{c}\mathbf{S}_{\mathbf{x}} \\
{\left[\mathbf{m}^{2}\right]}\end{array}$ & $\begin{array}{c}\mathbf{F}_{\mathbf{y}} \\
{\left[\mathbf{m}^{2}\right]}\end{array}$ & $\begin{array}{c}\mathbf{C}_{\mathbf{B}} \\
{[-]}\end{array}$ \\
\hline 1 & Pelican & 6000 & 137.0 & 21.35 & 12.5 & 7.32 & 7700 & 15500 & 2000 & 400 & 975 & 0.740 \\
\hline 2 & Gusto 5000 & 7000 & 140.0 & 28.0 & 13.3 & 9.8 & 14800 & 31500 & 2350 & 650 & 1400 & 0.795 \\
\hline 3 & Glomar Jack Ryan & 10668 & 210.0 & 36.0 & 17.7 & 11.0 & 37697 & 65000 & 4880 & 1150 & 2300 & 0.810 \\
\hline 4 & $\begin{array}{c}\text { Deepwater } \\
\text { Pathfinder }\end{array}$ & 11650 & 213.0 & 42.0 & 20 & 13.0 & 72700 & 103000 & 4950 & 1480 & 270 & 0.850 \\
\hline 5 & Gusto 10000 & 9600 & 194.4 & 30.0 & 19.1 & 11.0 & 26200 & 47200 & 3250 & 870 & 2200 & 0.800 \\
\hline 6 & Gusto P 10000 & 9600 & 211.0 & 35.8 & 17.8 & 12.0 & 51000 & 75000 & 3800 & 1210 & 2340 & 0.780 \\
\hline 7 & Navis Explorer I & 11278 & 185.7 & 40.0 & 19.5 & 12.2 & - & 70131 & 3950 & 1290 & 2250 & 0.800 \\
\hline 8 & Discoverer 534 & 7620 & 157.0 & 24.4 & 10.0 & 8.0 & 4200 & 21150 & 2350 & 480 & 1200 & 0.800 \\
\hline 9 & Glomar Eksplorer & 9144 & 180.0 & 35.4 & 15.5 & 10.4 & 27700 & 51300 & 2900 & 1100 & 1760 & 0.820 \\
\hline 10 & Discoverer Spirit & 10688 & 243.2 & 38.0 & 19.0 & 13.0 & 67000 & 105000 & 5100 & 1250 & 3100 & 0.850 \\
\hline 11 & Saipem 1000 & 9140 & 214 & 41.7 & 19.0 & 12 & - & 97000 & 5150 & 1400 & 2670 & - \\
\hline
\end{tabular}

Tab. 2. Sea conditions and DSP system's power output for drilling ships

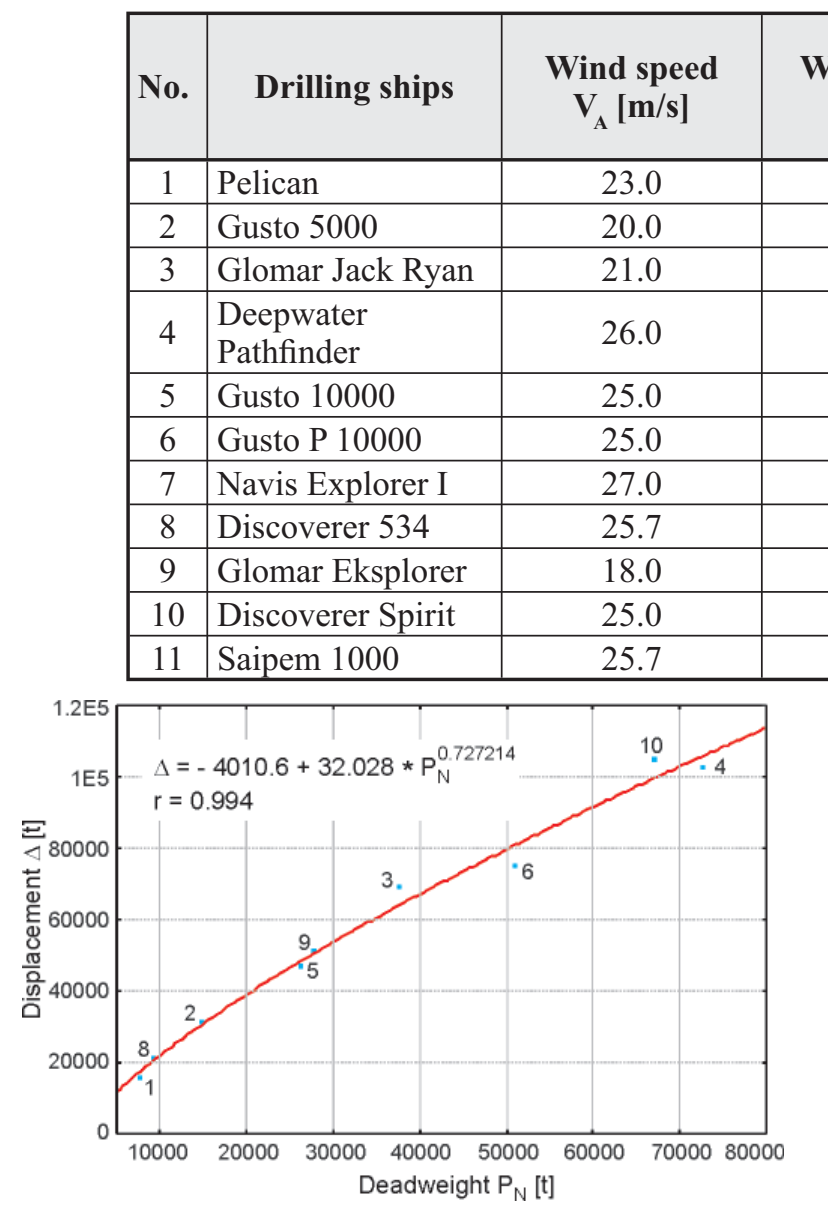

Fig. 2. Ship displacement $\Delta$ versus ship deadweight $P_{N}$ for drilling ships

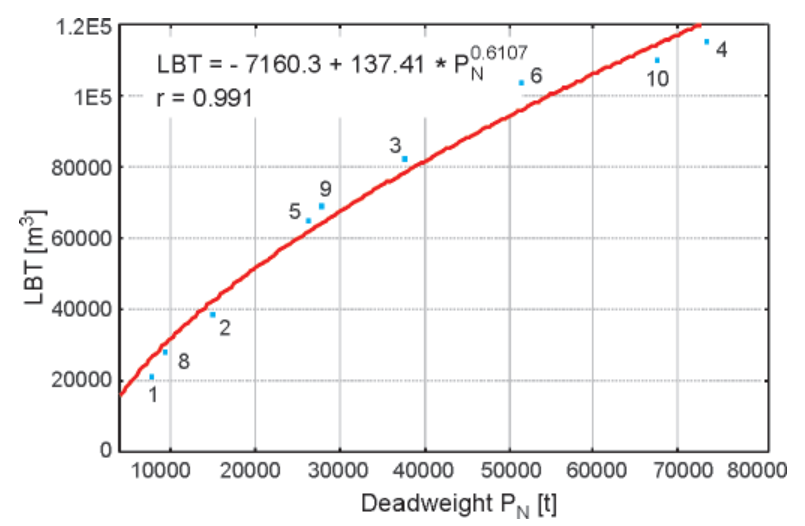

Fig. 3. LBT module of ship versus its deadweight $P_{N}$ for drilling ships

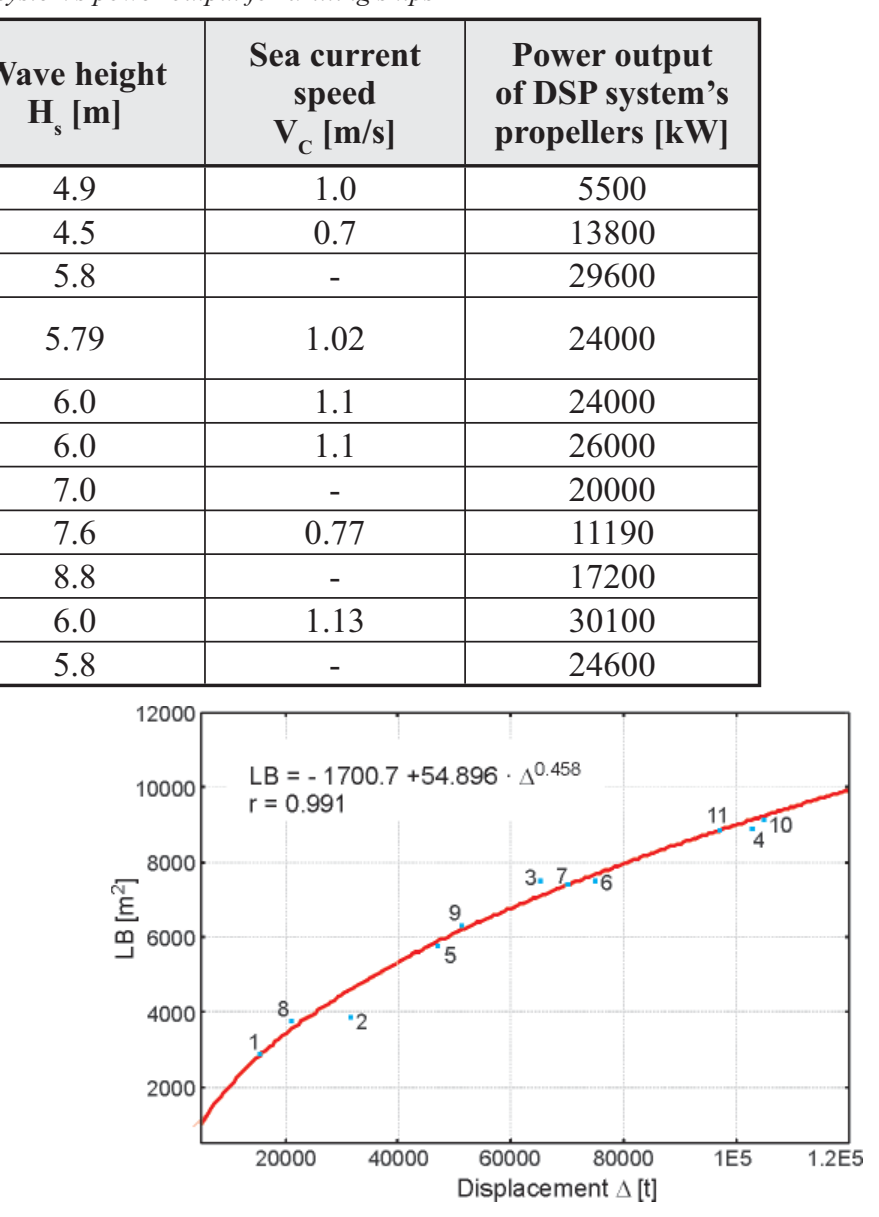

Fig. 4. LB product versus ship displacement $\Delta$ for drilling ships

The sets of all the functional relations together with the complete list of data on the group of the drilling ships taken into account in the analyses in question, are included in the publications [2] and [3].

The diagrams given below show the form of the searchedfor regression function which best represents course of the investigated parameters, as well as values of the correlation coefficient $r$.

For the mining ship the main initial parameter is the rate of winning the wet concretions $\mathrm{Q}_{\mathrm{MK}}$ from which the ship load carrying capacity $P_{£}$ results (assuming values of the time interval of storing the concretions in holds, $\mathrm{T}_{\mathrm{SK}}$, and the operation time interval $\mathrm{T}_{\mathrm{e}}$ ). To determine a size of the mining ship, first was determined a value of the load carrying capacity 
parameter on the basis of which the elaborated functional relations for drilling ships could be used.

The schematic diagram of determination first of mining ship deadweight and then its main dimensions and surface areas - with taking into account the design assumptions - is presented in Fig. 5.

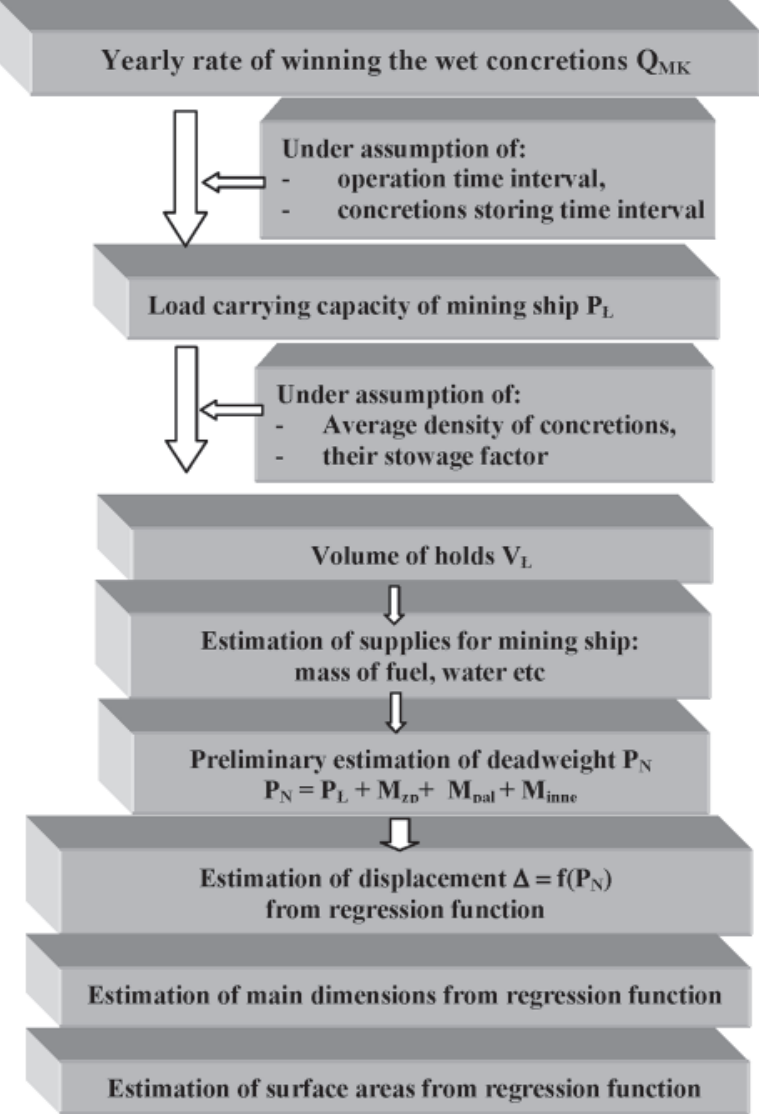

Fig.5. Schematic diagram of determination of main parameters and dimensions of mining ship in preliminary design stage
In order to determine the total deadweight of mining ship, $\mathrm{P}_{\mathrm{N}}$, additional supplies such as : fuel, water, mining process equipment etc were also determined by making use of the data on drilling ships [3]. The statement of values of particular supplies is presented in Tab. 3 .

Tab. 3. Statement of supplies, load carrying capacity and deadweight of mining ships for $T_{S K}=10$ [days]

\begin{tabular}{|c|c|c|c|}
\hline $\begin{array}{c}\text { Rate of winning } \\
\text { the wet } \\
\text { concretions } \\
\mathrm{Q}_{\mathrm{MK}}[\mathrm{t} / \mathrm{year}]\end{array}$ & 1.400 .000 & 1.750 .000 & 2.100 .000 \\
\hline $\begin{array}{c}\text { Number of crew } \\
\text { members } \\
\mathrm{n}_{\mathrm{z}} \text { [persons] }\end{array}$ & 155 & 160 & 165 \\
\hline $\begin{array}{c}\text { Mass of water } \\
\text { and food supplies } \\
\mathrm{M}_{\mathrm{wp}}[\mathrm{t}]\end{array}$ & 1465 & 1512 & 1559 \\
\hline $\begin{array}{c}\text { Mass of fuel } \\
\text { supplies } \\
\mathrm{M}_{\mathrm{pal}}[\mathrm{t}]\end{array}$ & 5382 & 5718 & 6073 \\
\hline $\begin{array}{l}\text { Mass of various } \\
\text { supplies } \\
\mathrm{M}_{\text {inne }}[\mathrm{t}] \mathrm{wg}[6]\end{array}$ & 110 & 110 & 110 \\
\hline $\begin{array}{c}\text { Load carrying } \\
\text { capacity } \\
\mathrm{P}_{\mathrm{t}}[\mathrm{t}]\end{array}$ & 48904 & 61130 & 73356 \\
\hline $\begin{array}{c}\text { Deadweight } \\
{[\mathrm{t}]}\end{array}$ & 55861 & 68470 & 80988 \\
\hline
\end{tabular}

The detail schematic diagram of determination process of mining ship parameters and main dimensions (expanded Block III of Fig. 5) together with the nonlinear regression functions of the largest values of correlation coefficient is presented in Fig. 6.

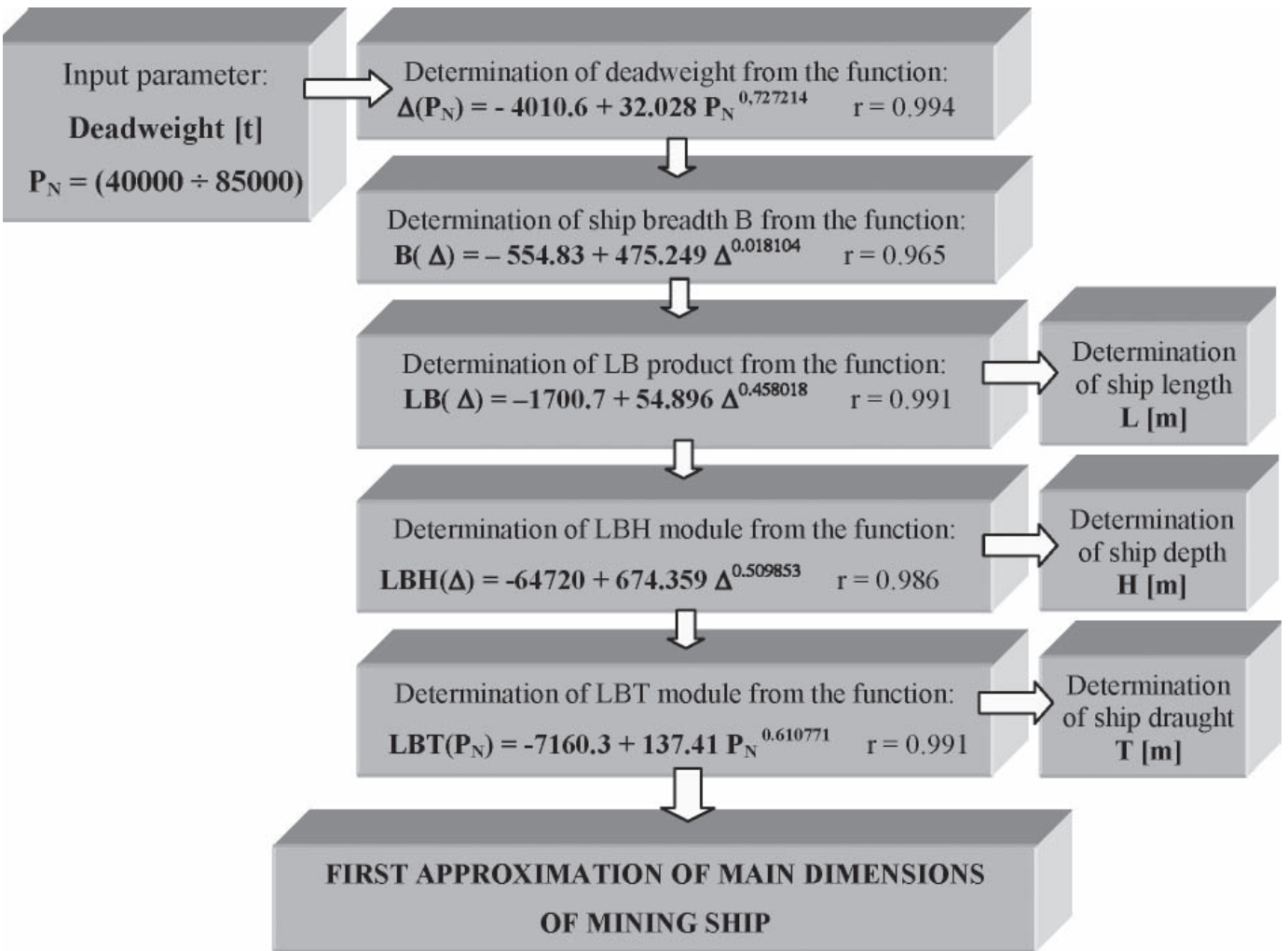

Fig.6. Schematic diagram of determination of main dimensions of mining ship 
The first results of determination of main dimensions of three variants of mining ship are presented in Tab. 4.

Tab. 4. Statement of the preliminarily estimated main parameters of mining ship (for $T_{S K}=10$ days)

\begin{tabular}{|c|c|c|c|c|}
\hline & Variant of mining ship & Variant 1 & Variant 2 & Variant 3 \\
\hline \multirow{5}{*}{ 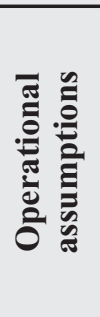 } & $\begin{array}{c}\text { Rate of winning the wet concretions } \mathrm{Q}_{\mathrm{s}} \\
{[\mathrm{t} / \mathrm{year}]}\end{array}$ & 1.400 .000 & 1.750 .000 & 2.100 .000 \\
\hline & Operation time interval [days/year] & 292 & 292 & 292 \\
\hline & Theoretical rate of winning [t/day] & 4795 & 5993 & 7192 \\
\hline & Average density of concretions $\left[\mathrm{t} / \mathrm{m}^{3}\right]$ & 2 & 2 & 2 \\
\hline & $\begin{array}{l}\text { Time interval of storing the concretions } \\
\text { [days] }\end{array}$ & 10 & 10 & 10 \\
\hline \multirow{9}{*}{ 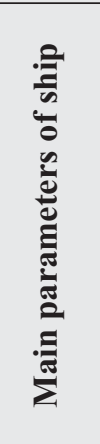 } & Ship load carrying capacity $\mathrm{P}_{\ell}[\mathrm{t}]$ & 48904 & 61130 & 73356 \\
\hline & Loading volume $\mathrm{V}_{\ell}\left[\mathrm{m}^{3}\right]$ & 22961 & 28684 & 34441 \\
\hline & Deadweight $\mathrm{P}_{\mathrm{N}}[\mathrm{t}]$ & 55861 & 68470 & 80988 \\
\hline & Displacement $\Delta[\mathrm{t}]$ & 86710 & 101200 & 114480 \\
\hline & Empty ship mass $\mathrm{M}_{\mathrm{SP}}[\mathrm{t}]$ & 30849 & 32730 & 33492 \\
\hline & Length b.p. $\mathrm{L}_{\mathrm{pp}}[\mathrm{m}]$ & 213.3 & 222.8 & 230.94 \\
\hline & Breadth B [m] & 39.05 & 40.68 & 42.02 \\
\hline & Depth H [m] & 18.9 & 19.37 & 19.74 \\
\hline & Draught $\mathrm{T}[\mathrm{m}]$ & 12.23 & 12.83 & 13.36 \\
\hline
\end{tabular}

\section{Verification of main parameters of mining ship}

Lack of information on quantity, weight and gabarites of special equipment as well as data on weights of particular technological - constructional classes of the elements was the reason that the ship's size (especially its length) was determined with a view of:

is demanded volume of the holds for temporary storing the concretions

is size of the engine room, which was determined on the basis of the relation $\mathrm{LB}_{\text {sit. }}=\mathrm{f}(\Delta)$ given in [1]

is value of superstructure surface area which was determined on the basis of the relation $\mathrm{LB}_{\text {nadb. }}=\mathrm{f}\left(\mathrm{n}_{\mathrm{z}}\right)$ and $\mathrm{L}_{\text {nad }}=\mathrm{f}\left(\mathrm{n}_{\mathrm{z}}\right)$ given in [1]

is dimensions of the winning casing (dependent on dimensions of bottom gathering vehicle)

is value of surface area for storing the pipes (dependent on winning operation water depth)

is volume of the compartment for preliminary cleansing the concretions (resulting from winning rate of winning devices).

For approximate verification of the determined parameters of mining ship the data on the ships converted - in the 1970 s - to the function of mining the concretions [1], [6], were used. The used data dealt with the displacement usage factor $\eta_{N}$ and that of load carrying capacity, $\eta_{f}$, as well as indices of the dependencies of the $\mathrm{LBH}$ and LBT volumetric modules, and that of LB area versus the ship displacement $\Delta$ and its deadweight $\mathrm{P}_{\mathrm{N}}$. Knowledge of the factors made it possible to introduce corrections to the dimensions of the designed variants of mining ship. First of all the ship's length, deadweight, displacement and main dimensions modules were corrected.

Additionally, after determination of the main dimensions the ship displacement was corrected on the basis of the displacement equation expressed in function of main dimensions:

$$
\Delta=\rho_{\mathrm{w}} \mathrm{k}_{\mathrm{p}} \mathrm{LB} \mathrm{T} \mathrm{C} \mathrm{B}_{\mathrm{B}}
$$

where:

$\mathrm{k}_{\mathrm{p}}=1.005 \div 1.01$ - allowance coefficient for ship's outer plating and appendages

The statement of the corrected main parameters and dimensions of the mining ships is presented in Tab. 5. Their operational assumptions dealing with winning rate and winning time interval, average density of the concretions are kept unchanged.

\section{Spatial arrangement of mining ships of simplified design concept}

The designed mining ship is of single hull. Compartments of its power plant, electric power plant together with auxiliary devices are located aft, and wheel house and living accommodations fore. Also in the bow part all the systems and devices associated with functioning the superstructure are located. The midship part is used to accommodate the following :

- the stabilized hoist tower and winning casing fitted with winning pipe line,

- the compartment containing the devices for preliminary cleansing the concretions and transporting them to holds,

the hold compartments (on aft and fore side of the cleansing compartment),

the supplies of winning pipes (stored on the platform over the aft holds and in the pipe store room fore).

The ship is fitted with double bottom extending fore and aft as well as double side structure along the working space. The double bottom spreads from the after-peak bulkhead to the collision bulkhead. The double bottom height was assumed equal to $3000 \mathrm{~mm}$ (on the basis of drilling ships) over its full length, and the breadth of double sides equal to $2500 \mathrm{~mm}$. The inner bottom is assumed flat over the whole breadth of hull, and the upper deck is of no sheer and camber.

If the breadth of double sides and double bottom height as well as the hold structure is taken into account, values 
Tab. 5. The statement of the corrected main parameters and dimensions of three mining ship design variants (for $T_{S K}=10$ days)

\begin{tabular}{|c|c|c|c|c|}
\hline & Variant of mining ship & Variant 1 & Variant 2 & Variant 3 \\
\hline \multirow{6}{*}{ 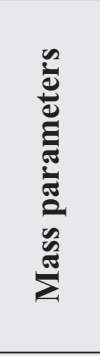 } & Number of crew members $n_{z}$ [persons] & 190 & 195 & 200 \\
\hline & Mass of water and food supplies $\mathrm{M}_{\mathrm{wp}}[\mathrm{t}]$ & 2713 & 2790 & 2856 \\
\hline & Mass of fuel supplies $\mathrm{M}_{\mathrm{pal}}[\mathrm{t}]$ & 9403 & 10439 & 12136 \\
\hline & Mass of various supplies $\mathrm{M}_{\mathrm{inne}}[\mathrm{t}]$ & 110 & 110 & 110 \\
\hline & Load carrying capacity $P_{t}[t]$ & 48904 & 61130 & 73356 \\
\hline & Deadweight $P_{N}[t]$ & 61130 & 75469 & 89458 \\
\hline \multirow{7}{*}{ 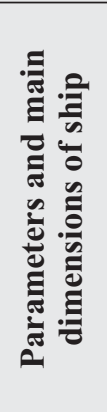 } & Length b.p. $\mathrm{L}_{\mathrm{pp}}[\mathrm{m}]$ & 203.5 & 215.6 & 230.1 \\
\hline & Breadth B [m] & 39.05 & 40.68 & 42.02 \\
\hline & Depth H [m] & 18.9 & 19.37 & 19.74 \\
\hline & Draught $\mathrm{T}[\mathrm{m}]$ & 12.23 & 12.83 & 13.36 \\
\hline & Hull block coefficient $C_{B}$ & 0.83 & 0.83 & 0.83 \\
\hline & Displacement $\Delta[\mathrm{t}]$ & 83100 & 96250 & 110500 \\
\hline & Volume of holds $\mathrm{V}_{\ell}\left[\mathrm{m}^{3}\right]$ & 22961 & 28684 & 34441 \\
\hline
\end{tabular}

of the length of the crucial compartments of the ship are as follows:

\begin{tabular}{|c|c|c|c|}
\hline Variant of mining ship & Variant 1 & Variant 2 & Variant 3 \\
\hline $\begin{array}{c}\text { Length of hold } \\
\text { compartment } \mathrm{L}_{\text {tad }}[\mathrm{m}]\end{array}$ & 48.4 & 55.6 & 62.5 \\
\hline $\begin{array}{c}\text { Length of engine room } \\
1_{\text {sił }}[\mathrm{m}]\end{array}$ & 37.0 & 39.0 & 41.0 \\
\hline $\begin{array}{c}\text { Length of superstructure } \\
1_{\text {nad }}[\mathrm{m}]\end{array}$ & 29.0 & 30.0 & 30.7 \\
\hline $\begin{array}{c}\text { Length of winning } \\
\text { casing [m] }\end{array}$ & 20 & 20 & 20 \\
\hline $\begin{array}{c}\text { Length of pipe storing } \\
\text { compartment [m] }\end{array}$ & On the basis of drilling ships \\
15
\end{tabular}

The research work [6] was used to prepare the general arrangement plan of the mining ship. In Fig. 7 the concept of general arrangement of one of the variants of the mining ship is presented.

\section{CONCLUSIONS}

Design of mining ship should be realized with a view of its effectiveness which consists a.o. in minimization of down - time interval (the time during which carrying out winning operations is not possible due to bad weather conditions) as well as minimization of unit winning cost (e.g. per $1 \mathrm{t}$ of concretions).

O The effectiveness is mainly influenced by the main parameters of ship, and consequently by power output of its motion control system, whose values depend a.o. on weather condition parameters. Therefore it is important to design a mining ship which constitutes an optimum from the point
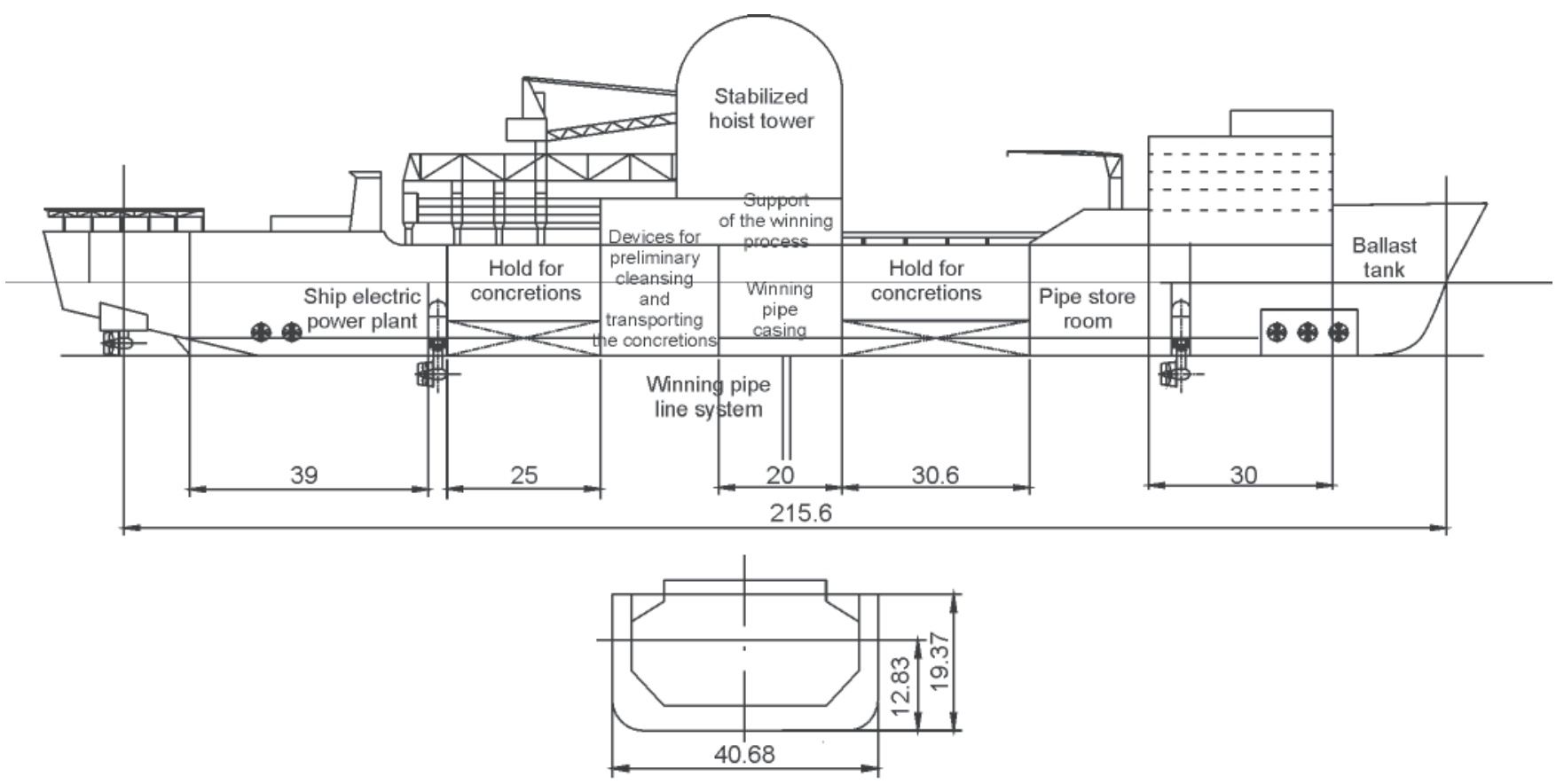

Fig.7. A concept of general arrangement of mining ship (based on the dimensions of Variant II ship) 
of view of its initial and operational costs as it will have prevailing impact on success of the entire undertaking.

In this paper were formulated the main design assumptions crucial for a size of ship for winning Fe-Mn concretions.

On the basis of the main design assumptions, namely : the yearly rate of winning $\mathrm{Q}_{\mathrm{MK}}$, the time interval of storing the concretions in ship holds, $\mathrm{T}_{\mathrm{SK}}$, as well as parameters of concretions deposit, the necessary load space of the mining ship was estimated. By making use of the data on drilling ships (deemed similar regarding their functions and space arrangement) and the functional relations between the main parameters and dimensions, the first preliminary concept of mining ship dimensions was elaborated. This way were determined the ship parameters which have not been so far fully defined and elaborated.

O The task was especially difficult because it concerned the mining system which contains many unknowns in the range of geometry and mass of the ship. Therefore the presented concept of mining ship's main parameters should be considered only as a preliminary source of information even if because the ship's displacement and its dimensions have not been verified by applying real values of weight and size of devices for winning and cleansing the concretions as well as of special equipment.

The elaborated preliminary design of the mining ship was already used a.o. for performing approximate analyses of power demand for such ship and mainly for estimation of electric plant power output including necessary power demand for the ship's motion control system.

\section{NOMENCLATURE}

B - ship breadth

$\mathrm{C}_{\mathrm{B}} \quad-$ hull block coefficient

$\mathrm{D}_{\mathrm{rz}}-$ outer diameter of winning pipe line

$\mathrm{F}_{\mathrm{y}}{ }_{\mathrm{rz}} \quad-$ projection area of hull underwater part surface to ship's plane of symmetry

$\mathrm{H} \quad-$ ship depth

$\mathrm{h}_{\mathrm{wr}} \quad-$ drilling depth

$1^{\text {wr }} \quad-$ length of winning pipe line

$\mathrm{L}_{\mathrm{rp}} \quad$ - ship length b.p.

$\mathrm{M}^{\mathrm{p}} \quad-$ mass of fuel supplies

$\mathrm{M}_{\mathrm{SP}}^{\mathrm{pal}}-$ mass of empty ship

$M_{\text {wp }}$ - mass of water and food supplies

$\mathrm{M}_{\mathrm{ZP}}^{\mathrm{wp}}-$ mass of supplies

$n_{z} \quad-$ number of crew members

$\mathrm{P}_{\mathrm{Z}} \quad-$ ship load carrying capacity

$\mathrm{P}_{\mathrm{N}} \quad-$ ship deadweight

$\mathrm{S}_{\mathrm{x}}, \mathrm{S}_{\mathrm{y}}-$ projections of windage areas (to midship plane and symmetry plane, respectively) $t_{p} \quad-$ yearly down-time interval due to bad weather conditions

$\mathrm{t}_{\mathrm{r}} \quad-$ yearly down-time interval due to technological reasons

$\mathrm{T} \quad-$ ship draught

$\mathrm{T}_{\mathrm{e}} \quad-$ effective operation time interval

$\mathrm{T}_{\mathrm{SK}}^{\mathrm{e}} \quad$ - time interval of storing concretions in holds

$\mathrm{V}_{\ell}-$ load volume

$\mathrm{V}_{\mathrm{s}} \quad-$ ship speed

$\mathrm{Q}_{\mathrm{MK}}-$ yearly rate of winning the wet concretions

$\mathrm{Q}_{\mathrm{SK}}$ - rate of winning the dry concretions

$\rho_{\mathrm{w}}-$ sea water density

$\Delta \quad-$ ship displacement.

\section{BIBLIOGRAPHY}

1. Бакуров Г.И.: Суда для глубоководных горнотехнологических исследованний, Судостроение, № 3, 1988

2. Bortnowska M., Szelangiewicz T.: Approximate method of determining power output of dynamic positionig system of drilling ships useful at preliminary design, Polish Academy of Sciences, Marine Technology Transactions, Vol. 16, 2005

3. Bortnowska M.: A method of determining power output of motion control system of floating unit during the winning of $\mathrm{Fe}-\mathrm{Mn}$ concretions, useful at preliminary design (in Polish), Doctoral dissertation, Szczecin University of Technology, 2006

4. Depowski S., Kotliński R., Ruhle E., Szamałek K.: Mineral rough materials of seas and oceans (in Polish), Scholar Scientific Publishers (Wydawnictwo Naukowe Scholar), Warszawa 1998

5. Sobota J.: Estimation of power demand for the systems of winning the concretions from sea bed (in Polish), Interoceanmetal Common Organization (Wspólna Organizacja Interoceanmetal), Szczecin 2003

6. Szelangiewicz T.: Concept design of the ship for winning $\mathrm{Fe}-\mathrm{Mn}$ concretions (in Polish), Theme D5, Ship Design Office (Biuro Projektowo-Konstrukcyjne), Szczecin Shipyard, Szczecin 1978

7. Szelangiewicz T.: Research on dynamics of the winning complex for exploitation of deep-sea- bed concretions (in Polish), Research project report, Szczecin University of Technology, Faculty of Maritime Technology, Szczecin 2006

\section{CONTACT WITH THE AUTHOR}

Monika Bortnowska, Ph. D.

Faculty of Marine Technology, Szczecin University of Technology

Al. Piastów 41

71-065 Szczecin, POLAND e-mail : mwojciechowska@ps.pl tel.: (091) 4494720

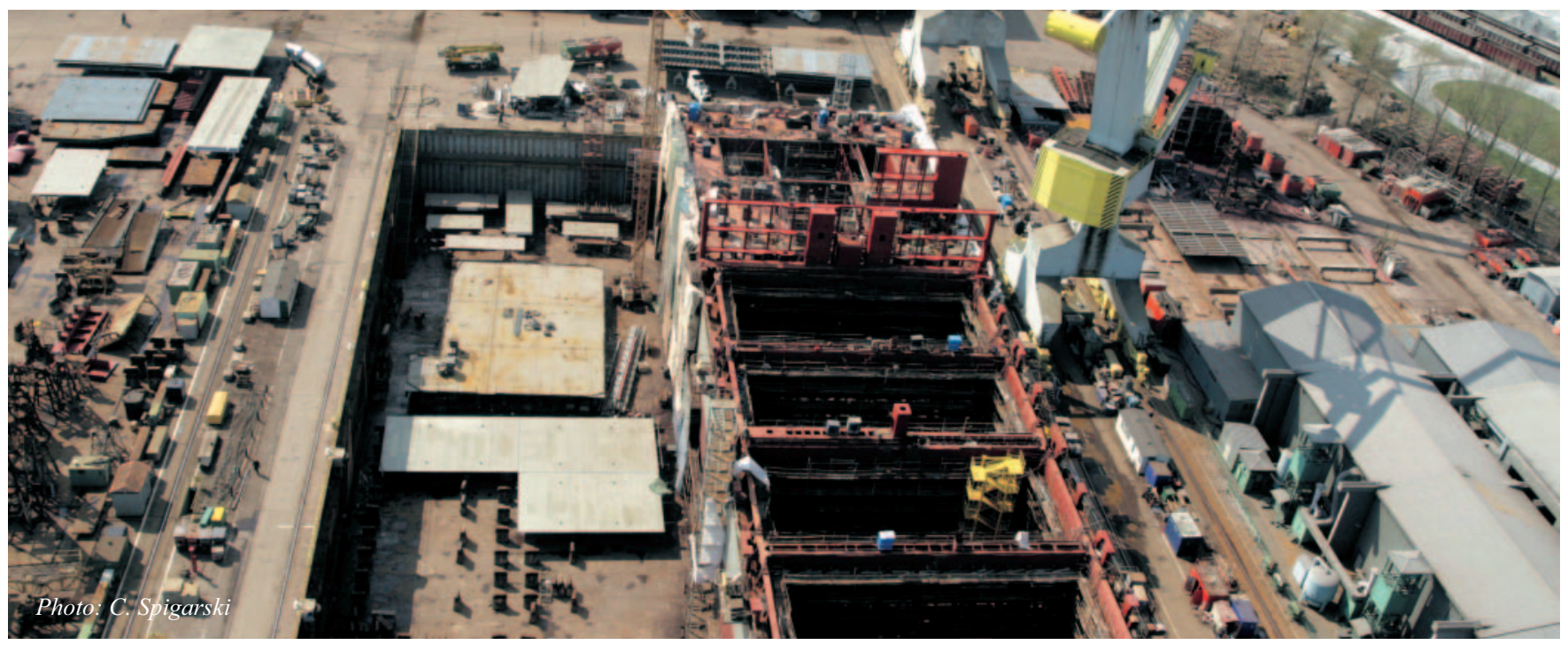

